\title{
The Arc of Liberalism and the Career of Harrison "Pete" Williams
}

\author{
Michael Kazin ${ }^{1}$
}

The following address was delivered by Michael Kazin of Georgetown University at the opening of the spring 2009 exhibit, "Crossroads: Senator Harrison A. Williams Jr. and Great Society Liberalism, 1959-1981," at Rutgers -New Brunswick's Alexander Library, January 27, 2009. The exhibition, which runs from January until August 1, 2009, commemorates the completion of a three-year effort to organize the papers of U.S. Senator Harrison Williams, Jr. of New Jersey. These papers are held in Rutgers University Libraries' Special Collections and University Archives.

It's particularly gratifying to be speaking at New Jersey's flagship public university because I got my first lessons in electoral politics in the Garden State as a young campaigner for liberal Democrats. I grew up in Bergen County, where I worked for JFK in 1960, for LBJ in 1964, for Governor Richard Hughes in 1965, and for a Democratic candidate for the House named Henry Helstoski, who was the first Democrat to win a seat in Bergen in living memory. In 1964, I also passed out a few leaflets for Harrison Williams. I would have done more than that, but he didn't need much help that year. Every single one of the candidates I campaigned for was victorious.

There was a bittersweet quality to those two presidential victories. The years 1960 and 1964 were the only times Democrats carried New Jersey from the last election of FDR in 1944 to the first victory of Bill Clinton almost half a century later. So I grew up with an inflated sense of optimism about the fortunes of American liberalism, which may account for my sunny outlook on life in general.

For all the attention that scholars and journalists give to the subject of liberalism, its true moments in the sun - when liberals dominated the political landscape - have been rather brief. There have been three great moments of liberal triumph, in elections and policy, during the twentieth century: 1913-1917; 1933-1939; 1961-1966. During each moment, Democrats enjoyed large majorities in both houses of Congress and had a president confident of his goals and able to carry most of them out. We tend to identify each of these periods exclusively with a liberal in the White House and the campaign slogan each man coined to give an uplifting, progressive tone to his policies: Woodrow Wilson and

\footnotetext{
${ }^{1}$ Michael Kazin is a Professor in the Department of History at Georgetown University. He is an expert in U.S. politics and social movements and is currently working on a history of the American left, to be published by Knopf. His most recent book is A Godly Hero: The Life of William Jennings Bryan (New York: Knopf, 2006).
} 
his "New Freedom." FDR and his "New Deal." John Kennedy's "New Frontier" and Lyndon Johnson's "Great Society."

But each of these presidencies ended in tragedy. Two of the four liberal presidents died in office, one by assassination. The other two left the White House as unpopular figures who probably would not have won re-election even if they had managed to receive a second nomination. But fortunately, their legacies are much brighter: many of the policies they signed into law endure - and they continue to form the basis of much that is humane and equitable about how the federal government treats Americans today. And those accomplishments are due as much to the abilities of liberals in Congress - like Harrison Williams - and a supportive Supreme Court as they are to the far better publicized deeds of presidents.

One can think of these policies as tracing a ever-widening arc of liberalism. It is an arc that begins with one type of reform impulse and gradually swells over time to encompass a broader set of concerns and to aid a greater number and more diverse group of American citizens - and potential citizens. Most of you are probably familiar with the axiom of the abolitionist Theodore Parker written in the 1850s, often quoted by Martin Luther King, Jr., a century later: "The arc of the moral universe is long, but it bends toward justice."

It's an apt way to think about the evolution of liberal governance. Think of the highlights of each liberal moment:

During the Wilson years, Congress passed the first laws to give some workers an eighthour day, enacted a tough anti-trust Law, and made controlling the money supply a public responsibility by initiating the Federal Reserve System. The first prominent Democrat to champion these ideas was William Jennings Bryan. But Bryan, although an eloquent populist, was too polarizing a figure to win a national majority. Aided by a bitter split in the opposition party, Woodrow Wilson and congressional Democrats were able to enact them. But Wilsonian liberalism was a cramped version of that ideology. Wilson abetted racial injustice by segregating parts of the federal government and tacitly supported Jim Crow laws in the states. And his messianic motivation for sending US troops to fight in World War I failed to bring about the democratic world order he had promised.

During the FDR years, Congress enacted Social Security, created jobs for millions of the unemployed, passed the GI Bill of Rights, and the Wagner Act - a virtual bill of rights for workers seeking to organize unions. And lawmakers appropriated the funds that made it possible to defeat the armies of fascism in Europe and militarism in East Asia. But both the Social Security and Wagner Acts excluded two industries in which black and Latino Americans proliferated: domestic labor and agriculture. And FDR did nothing notable, either in word or deed, to support civil rights. He shrank away from challenging the power of Southern Democrats in Congress and alienating the white Southerners who had long been the bedrock of the Democratic coalition. 
By the time Harrison Williams got to the Senate in 1959, liberalism was becoming more genuinely liberal than ever before. His generation of Northern Democrats rejected the whole corpus of racist laws and the ideologies behind them. And they passed laws that guaranteed women more equal treatment in the workplace and which protected the environment. Williams and his liberal colleagues were still closely aligned with the labor movement. But they succeeded in expanding the protection of labor laws to include groups of workers left out during the New Deal.

In foreign affairs, the great cause of liberals through the first half of the 1960s was, of course, battling Communists in the Third World. During the Kennedy administration, most liberals believed this cause was essentially the same one they had fought for during World War II - to defend freedom against tyranny. But the bloody debacle in Vietnam led many of them to question that belief or abandon it entirely.

Every previous liberal moment was followed by a conservative one - and the moment that Harrison Williams took part in was no different. As president, Richard Nixon did not try to reverse most of the programs of the New Frontier and Great Society. In fact, he extended a few of them - particularly in the area of environmental protection. But Nixon started to build a new coalition on the right that would triumph with Ronald Reagan in 1980.

Despite that setback, the arc of liberalism did bend toward justice. The populism of Bryan wedded Democrats to bottom-up economic policies from anti-trust to the income tax and won the support of organized labor. The liberalism of Woodrow Wilson expanded the circle of concern to the urban poor and, however imperfectly, to the victims of colonial rule. The New Deal brought industrial workers, Catholic ones in particular, into the liberal coalition and finally abandoned the old reluctance to use the federal government to stabilize the economy. FDR and his supporters laid the basis for such Great Society measures as Medicare and the Civil Rights act which changed the lives of as many Americans as Social Security and the Wagner Act.

Beyond each individual reform and piece of legislation, liberals won a larger and more durable victory. They changed what Americans think the duties of government and business ought to be. The liberal wisdom, one shared with social democrats elsewhere in the developed world, is to combine what both the state and the market do well: the market cannot be trusted to operate for the public good but neither can the state produce economic growth or innovation unless it cooperates with entrepreneurs, employers, and workers. This is a magic formula of sorts; it combines the best elements of capitalism and socialism - of free competition with the need for regulation and social solidarity. As President Barack Obama put it in his inaugural address, "a nation cannot prosper when it favors only the prosperous."

Whatever the election results, this wisdom has proved quite durable. A plurality of Americans may still call themselves "conservative" and wonder if the government can solve social and economic problems. They dislike "big government" - but they love federal programs, as long as they benefit them and anyone else they regard as morally 
worthy: the elderly, children, veterans, workers who show up every day and do a decent job. Americans also want government to stabilize the economy; in the current crisis, they are pleading that it do so.

In the mid-1960s, during the heyday of the Great Society, two political scientists identified a classic paradox that remains as true now as the day it was written: most Americans, they wrote, are ideological conservatives but they are operational liberals. ${ }^{2}$ So the arc of liberalism bends toward justice - but that doesn't mean it does so smoothly or without developing cracks and weaknesses and occasional dips along the way.

The arc of Harrison Williams's Senate career almost exactly coincided with the rise, decline, and end of the third - and, so far, last - period of liberal dominance. He was elected to the Senate in 1958 - one of a remarkable group of thirteen new Democratic members which included Edward Muskie, Philip Hart, William Proxmire, and Eugene McCarthy. He was then re-elected by twenty-five points in the Democratic landslide of 1964. In 1970, Williams had a more difficult race. He had turned against the war in Vietnam by then - and that stance earned him a primary opponent. In the general election, Williams had the dubious honor of having the president of the United States come to the Garden State to campaign against him. Inevitably, the press called it a "battleground" race. In fact, it wasn't much of a fight: Williams won another easy victory - by twelve points. Six years later, he benefitted from the post-Watergate climate to win by another landslide.

Of course, his Senate career came to a sad and embarrassing end. But his resignation occurred at a time when liberalism had gone into temporary eclipse as well. Ronald Reagan was president, and for the first time since Williams came to Congress, Republicans had a majority in the Senate. The arc of his career had turned sharply downward along with the arc of his political faith.

But the range of what he helped accomplish in the Senate illustrates the breadth of what liberalism had become in post-World War II America. Like many of his colleagues - and both Jack Kennedy and Richard Nixon - Williams was a veteran of that war.

For most Americans, World War II was and remains "the good war" - one truly fought to defend democracy around the world. And soon after it ended, a very good peace began: the U.S. and the rest of the industrial world entered an economic golden age, in which real incomes doubled in a generation. For the first time in history, hundreds of millions of people were able to buy a house or apartment, an automobile, and take an annual vacation. Also, for the first time in U.S. history, the average American considered him or herself to be middle-class. Here and in many European countries, a college education became a middle-class experience, not one restricted mostly to the wealthy. This golden age made a more generous, more liberal liberalism possible.

\footnotetext{
${ }^{2}$ Lloyd Free and Hadley Cantril, The Political Beliefs of Americans (New Brunswick: Rutgers University Press, 1967).
} 
Harrison Williams seems to have brought to Congress a sense of mission drawn in part from his wartime service - and a determination to expand economic security and middleclass status - to groups earlier liberals had neglected.

In 1967, as chair of the Senate Subcommittee on Migratory Workers, he held hearings in Texas to support the efforts of labor organizers in the fields. He opened the hearings with this ringing statement: "We are trying to bring farm workers the same opportunities of democratic organization and unionization that industrial workers have. Farm workers at last are going to be brought into the mainstream of life."

In 1969, he spearheaded an effort to end what he called the "primitive" conditions in coal mines by limiting the amount of coal dust that miners inhaled - and imposing large fines on companies that delayed installing safety equipment or were convicted of violating safety laws.

In 1977, Williams took a leading role in passing legislation that later became the Pregnancy Discrimination Act. The Senator explained, "the overall effect of discrimination against women because they might become pregnant, or do become pregnant, is to relegate women in general, and pregnant women in particular, to a secondclass status."

And he was also ahead of many liberal politicians in working to preserve the environment. In 1961, Williams introduced a measure to give grants to state and local governments to preserve open space from swiftly growing cities and suburbs. This wasn't a popular measure with either powerful construction unions or with the companies that built housing and highways. But Williams understood the need to improve the quality of life for Americans as well as to keep the economy humming.

When he first ran for the Senate in 1958, the New Jersey affiliate of Americans for Democratic Action, that arch-liberal group, endorsed Williams. They said his record in the House of Representatives had demonstrated that he understood a range of issues, foreign and domestic. They added that he had "a freshness of outlook and sensitivity toward the rights and yearnings of all the people." It is a good summary of the Senate career to come.

But even as Williams and his fellow liberals were gaining strength in Congress and winning the White House, a conservative opposition was growing. Most businessmen had never been happy with the New Deal, which raised their taxes and empowered unions. After World War II, they organized aggressively to turn back federal power, to block any further advances by the labor movement, and to elect like-minded politicians to office. Corporations like General Electric and Kohler, the toilet manufacturer, took a leading role in this effort. The American Enterprise Institute was one fruit of their labors. GE hired Ronald Reagan to give speeches and appear on television for its sponsored programs - and the experience of promoting a conservative outlook prepared him to run for Governor of California a few years later. At the same time, the John Birch Society was growing rapidly, driven by the fear that every optimistic liberal was a godless 
Communist in disguise. Barry Goldwater's 1964 presidential campaign drew activists from both the rational and irrational elements of this movement.

Goldwater's historic drubbing in that election did not dishearten his followers. In fact, the campaign transformed the American right from a small, largely intellectual and corporate phenomenon into a major grassroots force. By the end of the 1960s, that movement was on the march and had stopped a good deal of liberal legislation in its tracks. And liberals were increasingly divided from within over a number of major issues: affirmative action, the war in Vietnam, the counter-culture of the young. At the same time, a big increase in urban crime helped cause a backlash against liberal policies of leniency toward offenders, most of whom were poor and many of whom were black or Latino.

Harrison Williams confronted that problem in a more personal way than he would have liked. In the summer of 1969, he was robbed in the garage of his apartment house in Washington. The mugger pointed a gun at his head and took the $\$ 28$ that was in his wallet.

And the Vietnam War, which Williams turned against by 1970, probably did more damage to the liberal cause than anything else that occurred during his time in office. It produced the largest anti-war movement in history, led by people who accused powerful liberals of moral hypocrisy at best, and genocide at worst. And LBJ's failure to defeat an army of Vietnamese peasants made liberals look weak and divided in projecting American power overseas - an image that dogged them until George W. Bush's own failure in Iraq.

So the third moment of modern liberalism ended amid internal strife and the perception of policy failure and social disorder.

But what about the future? This is always a perilous subject for a historian - but a week after Inauguration Day, I'm pretty sure it's a subject on everyone's mind.

Can Barack Obama and the Democratic Congress preside over a fourth liberal moment?

Obama himself certainly shares two traits that brought success to Wilson, FDR, and Kennedy: he is a gifted speaker and, so far at least, an enormously skillful politician. He is also the first liberal politician on the national stage since Robert Kennedy who inspires not just confidence but love.

And his election and high approval rate are evidence that the fears and inequalities of race which bedeviled liberals in every previous era have decreased considerably. In daily life, in a growing number of businesses and schools - and especially in popular culture racial diversity has become a given, despite what people may mutter under their breath. This environment made Obama's remarkable campaign possible; the idea of nominating a youngish bi-racial figure with a "funny name" and liberal positions would have been inconceivable as recently as 2000. "White America got used to black people turning up everywhere, except next door," observes the novelist Darryl Pinckney. The Obama 
campaign managed to give many Democrats and some independents a sense that "something historical was happening, that an unprecedented national narrative was taking shape." 3

But getting beyond race is not enough to sustain a liberal revival. To build a new majority coalition in a post-industrial, globalized nation will require a program and mode of persuasion distinct from those which worked in previous eras of liberal advance - the Wilson years, the New Deal, and the Great Society.

A majority of Americans are certainly ready for big changes. For now, that majority trusts Obama to carry them out. On health care, infrastructure spending, tax increases for the wealthy, steps to reverse global warming - he certainly has a mandate. But in those earlier moments, liberals were pushed by a social movement from below: by labor and small farmers in first two periods, by the black freedom movement and, to a lesser degree, feminists and environmentalists in the third. Is there such a movement now?

I think there is, but it's not one that looks like the earlier ones, which did not imagine themselves helping to govern the country. The movement that helped elect Obama is actually quite rare in U.S. history - it's a liberal insurgency. The insurgency is inspired by the traditional ideals of the left but it is eager and able to work within the boundaries of conventional party politics.

As with any mass movement, the current one did not emerge from a historical vacuum. Besides the obvious precursor of the black freedom movement, the Obama campaign benefitted from a decade of work by grassroots liberals, most from professional backgrounds, who were determined to pose an alternative to the conservative juggernaut.

The new liberal movement began a decade ago with a spasm of outrage against the impeachment of Bill Clinton and gathered force after the infuriating conclusion of the 2000 election. By 2008, the twin debacles of the Iraq war and the failure to save New Orleans and its people guaranteed that millions of Americans would be desperate to break the right's grip over the nation's affairs.

Obama understood this longing and infused his campaign with rhetoric and an organization that converted disgust into activism. As some clever liberal blogger wrote to vanquished Republicans the day after the election: "Now you know what a community organizer does."

This liberal movement is an influential force, but it is based on a demographic anomaly: it's drawn largely from members of the educated classes, mostly white, but its success depends on the support of wage-earners and their families, most of whom are black and Latino. As a voting bloc, this coalition has been forming since the 1990s. But the activist core is still mostly white and well-educated. Obama and his political advisors would like to use this grassroots force to support administration policies. But a true social movement isn't organized from the top down and particularly not from the West Wing.

\footnotetext{
${ }^{3}$ Darryl Pinckney, "Dreams from Obama," New York Review of Books, March 6, 2008, 41.
} 
Whether or not we will live during another great liberal moment is also connected to the health of the opposition. During the Wilson and Johnson administrations, conservatism was defeated politically but not ideologically. The New Deal years were an exception to this, which is a big reason why the New Deal era lasted into the early 1950s - and made its most important policy changes bedrock elements of our system.

Politically, the Republican Party is not in terrible shape. They hold governorships in three of the four biggest states and in lots of smaller ones. They also have a good chance of picking up seats in the House in 2010, when Obama will not be on the ballot.

But ideologically, the conservatives who control the GOP face a dilemma: their three biggest issues over the last 30 years - opposition to "big government," defense of "traditional values," and an aggressive stance towards evil regimes abroad have all lost popularity and salience.

So what will conservatives do? If they decide to return to first principles, they will be talking only to the ranks of the already convinced - and those ranks are filled largely by white Protestants, who are a declining segment of the population. But if conservative Republicans move to the center, they will alienate their party's base. And no politician ever wants to do that.

So the prospects for a new liberal moment depend, in part, on the continuing unpopularity and disunity of the conservative alternative. In politics as in sports, the smartest strategy is to be lucky enough to draw an opponent who doesn't have one.

But for a fourth moment of liberal triumph to occur, liberals will have to do more than just build a strong coalition and be lucky. They will have to recapture the sense of excitement, of dynamism that characterized the liberal arc in earlier times. They will have to convince Americans that liberalism owns the future, that it can define what the future should look like. This cannot be accomplished mainly with stirring, hopeful oratory, though that certainly has its place. What's needed is a clear, vibrant road map of how to progress through the current set of crises to a more decent and egalitarian future - to a government and economy that do not just secure and increase the quantity of goods and services Americans enjoy but which enhance the quality of our common life. And in that very liberal pursuit, one could do worse than learn from the career of Harrison Williams. 